\title{
Rethinking the Basis And Relevance of the Law of Perjury: a Pathway to its Resuscitation
}

\author{
${ }^{1}$ LL.B Calabar, B.L Nigeria \\ ${ }^{2}$ B.Sc Ebonyi, LL.B Ilorin, B.L Nigeria, AICRM, AICMC Nigeria \\ ${ }^{3}$ LL.B Calabar, AICMC Nigeria
}

Okpa Ujong Bassey ${ }^{1 *}$, Amadi Anyakweh Miracle ${ }^{2}$, Ndubueze Ebere Lene ${ }^{3}$

\begin{abstract}
DOI: $10.36348 /$ sijlcj.2020.v03i03.002
| Received: 17.03.2020 | Accepted: 24.03.2020 | Published: 27.03.2020
\end{abstract}

*Corresponding author: Okpa Ujong Bassey

\section{Abstract}

Perjury as an offence has often been relegated to the confines of paper books. This is despite the tons of witnesses and deponents who intentionally and willfully base their testimonies on falsehood and lies, and the plausible sanctions spelt out in various criminal codes, making the reason for the lukewarmness of the offence a wonder and its relevance a doubt. It is for this reason that this thesis emerged. This paper, therefore, evaluates perjury from majorly four countries of Nigeria, United States, Scotland and India, exposes what their law on perjury is, compares their different provisions as it bothers on what can be perjurious, analyses the basis of the law and highlights thoughts to help cover the loopholes in the law. The paper further explores judicial attitude to legal lies, the circumstances where perjury is said to have been committed and the conviction therein, making a comparison of the decisions. The paper is concluded with several observations, challenges facing the seeming irrelevance of the law and offer of recommendations. Some of the suggestions is to limit the definition of perjury, extend its scope to claimants and plaintiffs, extend criminal culpability in the law to persons who aided and counseled the perjury, as well as the parastatals in charge of justice remind lawyers and the public on the effect of perjury and the need to enforce it.

Keywords: Witness, evidence, deponent, perjury, question, oath, falsehood, question.

Copyright @ 2020: This is an open-access article distributed under the terms of the Creative Commons Attribution license which permits unrestricted use, distribution, and reproduction in any medium for non-commercial use (NonCommercial, or CC-BY-NC) provided the original author and source are credited.

\section{INTRODUCTION}

The purpose of criminal law is to, among other things, protect the society from harm; harm that may come to it directly or through indirect means. And in accomplishing this, the role which deterrence, as a theory of punishment, plays to both actual and prospective offenders is abounding. Criminal law is the law of crimes and what amounts to crime is not novel as it has been defined by the criminal law of variety of countries [1]. For instance, section 2 of the

Nigerian Criminal Code Act defines it is as an act or omission which renders the person doing the act or making the omission liable to punishment under any Act or law [2]. It has also been defined as an act or

\footnotetext{
1 The term "crime" does not have any simple or universally accepted definition in modern criminal law, with different statutes proffering different definitions.

${ }^{2}$ Cap. C38 Laws of the Federation of Nigeria (LFN) 2004. The section in view uses the word "offence" as
}

omission which constitutes an offence and is punishable by law [3] by either a term of imprisonment or fine, or both. It has, however, been stated [4] that the most popular view is that something is a crime if declared as such by the relevant and applicable law. That said, it is a general ideology that when we think crime, we focus on violent and property crimes such as homicide, rape, robbery, kidnapping, burglary and stealing, completely sidelining other anti-evidence acts condemned by the State such as perjury or false evidence.

Perjury (or false evidence, as it is sometimes coined) is a law on evidence recognized by various States and countries. They are generally crimes that

against "crime" and is a reproduction of section 2 of the Queensland Criminal Code Act of 1899.

3 See Garner B. A. (ed), (2012). Black's Law Dictionary $\left(10^{\text {th }}\right.$ ed, p. 451). Thomson Reuters.

${ }^{4}$ Farmer L. (2008). Crime, Definitions of. In Cane and Conoghan (Eds.), The New Oxford Comapanion to Law (p. 263). Oxford University Press. 
hinge their bearing on the incredibility of witnesses; evidence and declaration of witnesses who constantly find themselves appearing before the court or who depose to evidential documents such as affidavits for reasons too ambiguous to begin listing. As express and recognized in various jurisdiction as this law is, its relevance and place constantly appears to be arid. The rationale behind this is something one cannot specifically fathom without wondering whether he is correct in his assertion. On the one hand, one will attribute the loss of value to the constancy of the offence, and on the other on the rules of evidence on criminal procedure which, more than often, allows conviction of an accused only after the facts of the commission of the offence have been proved beyond reasonable doubt. [5]. If one should align with the second theory, the question of what becomes the purpose of requiring more than one witness to convict a perjured witness arises. And if we decide to leave the theories and pay a visit to the concept behind the lack of value for perjury, the challenge posed by the discrepancy between willful perjury and memory related perjury or between factually true yet questionevading and an erroneous version of the facts, as well as the judicial position for ambiguous questions asked in a proceeding will surface. What will come to the fore extends to even more than this as the novelty of the ideas, reasoning and structure of this work cannot be overemphasized.

With the unhidden knowledge that our courts are courts of facts not truth, and the truth can easily be non-factual as it sometimes is hay to prove, it is the aim of this paper to peruse the mischief rule of interpretation by exposing the reason behind the law of perjury, empathize at the difficulty in recognizing what should be perjurious and what is actually perjurious, and safely arrive at a concept which will bring back the court-of-justice prestige of our judiciary.

\section{The Scope and Constituents of Perjury}

Like most aspects of law, not every happening whose occurrence coincides with the course of a trial is perjurious or will amount to false evidence. Putting that phrase differently, one would say that certain elements must be present before the infraction of a law which may amount to perjury or an allied offence would take a stroll to the mind. In a bid to identify and expound on what constitutes perjury generally, it would not be unwise to, first, define the subject matters in consideration [6].

\footnotetext{
${ }^{5}$ See Woolmington v. Director of Public Prosecutions (1942) A.C. 1

${ }^{6}$ It is worthy of note that even though perjury, false evidence and fabricating evidence are like offences, their elements may differ at various times.
}

Perjury has been defined [7] as the intentional act of swearing a false oath or falsifying an affirmation to tell the truth, whether spoken or in writing, concerning matters relating to an official proceeding. In defining perjury, the Nigerian Supreme Court [8] restated the first paragraph of section 117 of the Nigerian Criminal Code Act when it pronounced:

Any person who, in any judicial proceeding or for the purpose of instituting any judicial proceeding, knowingly gives false testimony touching any matter which is material to any question then depending in that proceeding, or intended to be raised in that proceeding, is guilty of an offence, which is called perjury. [9]

In the United States, the offence has been widely defined and codified, thus:

Whoever having taken an oath before a competent tribunal, officer, or person, in any case in which a law of the United States authorizes an oath to be administered, that he will testify, declare, depose, or certify truly, or that any written testimony, declaration, deposition, or certificate by him subscribed, is true, willfully and contrary to such oath states or subscribes any material matter which he does not believe to be true; or whoever in any declaration, certificate, verification, or statement under penalty of perjury...willfully subscribes as true any material matter which he does not believe to be true; is guilty of perjury. [10]

Before taking a step further, it is germane we see how false evidence has been defined by statutes. Section 156 of the Penal Code of Nigeria and section 191 of the Indian Penal Code define false evidence by saying,

Whoever, being legally bound by an oath or by any express provision of law to state the truth or being bound by law to make declaration

\footnotetext{
${ }^{7}$ Ogbah I. (2017). Defence of Alibi (pp. 185-186). Legal Jurisprudence Limited.

${ }^{8}$ In the case of Omoregie v. Director of Public Prosecutions (1962) NSCC 107 SC

${ }^{9}$ This definition is a verbatim vomit of section 123 of the Queensland Criminal Code Act of 1899.

${ }^{10}$ Section 1621 of title 18 , United States Code
} 
upon any subject, makes any statement, verbally or otherwise, which is false in a material particular and which he either knows or believes to be false or does not believe to be true, is said to give false evidence [11].

The constituents of perjury or false evidence will be distilled from the above provisions and allusions, highlighting the prevailing variances in the various jurisdictions.

Existence of a witness or deponent. Witnesses and deponents are to perjury what judges are to the judiciary. There will be no law of perjury without witnesses in court or deponents to depositions. On who a witness is, the Nigerian Court of Appeal in Idowu $v$. Olorunfemi \& Ors, [12] said "the term 'witness' in its strict legal sense means one who gives evidence in a cause before a court and in its general sense includes all persons from whose lips testimony is extracted in any judicial proceeding." And a deponent has been defined to be a person who testifies by deposition or a witness who gives written testimony for later use in court [13]. Under the elements of perjury, the competence or admissibility of the witness is immaterial in establishing the commission of perjury or false evidence in certain jurisdiction [14].

Prevalence of judicial proceeding. Judicial proceeding is the regular and orderly progression of a lawsuit, including all acts and vents between the time of commencement and the entry of judgment [15]. It also includes any proceeding in the court, tribunal, or an inquiry where evidence may or may not be taken on oath [16]. Section 205 of the Nigerian Evidence Act 2011 posits that all oral evidence in any judicial proceeding must be given upon oath or affirmation administered in accordance with the provisions of the Oath Act of 2004 [17].

${ }^{11}$ It must be noted that while the Criminal Code Act is
the main regulatory legislation of criminal law in
Southern Nigeria, it is the Penal Code that is recognized
in Northern Nigeria.
${ }^{12}$ (2013) LPELR-20728(CA)
${ }^{13}$ Garner supra at p. 532
${ }^{14}$ See the fifth paragraph of sections 117 of the Nigerian Criminal Code Act and 123 of the Queensland Criminal Code Act 1899, for instance.

${ }^{15}$ Garner, supra at 976 and 1398.

${ }^{16}$ See sections 113 and 9 of the Nigerian Criminal Code Act and Penal Code respectively, as well as section 1(2) of the English Perjury Act 1911.

${ }^{17}$ The exceptions to this general rule are the provisions of sections 208 and 209 of the said Act. In effect, persons with religious objections to oath taking can be exempted from taking oath as well as anyone who is
From the wordings of the first paragraph of section 117 of the Nigerian Criminal Code Act already produced above, perjury is not confined to giving false testimony as a witness in an ongoing proceeding. It extends to doing so with the slightest intention of instituting any judicial proceeding as a deponent, where judicial proceeding is imminent or threatened. All that matters is the false evidence or testimony have a linkage with the judicial proceeding. Besides, under the

Criminal Code Act, the falsehood must not be sworn. This simply infers that the Criminal Code Act of Nigeria frowns at simply telling lies; even lies told outside the confines of a Court of Law are brought within the classification of perjury. The mental element or mens rea of 'knowingly' must be unwaveringly present. The Nigerian Supreme Court navigated this path and settled in it when it held in Omoregie $v$. Director of Public Prosecution [18] that on a charge of perjury, the prosecution must prove that the accused gave the testimony knowing it to be false.

Statements on oath or affirmation. With the presence of Section 205 of the Nigerian Evidence Act 2011 which posits that all oral evidence in any judicial proceedings must be given upon oath or affirmation [19] and administered in accordance with the provisions of the Oath Act of 2004, [20] it is not a prerequisite for the law of perjury under the Nigerian Criminal Code Act. Section 117 of the said the said Act stressed this point when it outlined in the second paragraph of the section that it is immaterial that the testimony is given on oath or under any other sanction authorised by law. The implication is that even lies told outside the confines of a Court of Law, whether sworn or not, are brought within the classification of perjury in the Southern principal criminal enactment of the Country. It is worth mentioning that the rules for perjury also apply where a person has made a statement under penalty of

less than the age of 14 years of age at the time of the oath taking or affirmation.

18 Supra. There, the Court set aside the perjury conviction and 6 months sentence of the appellant on the ground that the appellant was summarily convicted by the trial court for the perceived false evidence he gave in the civil matter which was before the trial court. ${ }_{19}$ The tenth edition of the Black's Law Dictionary as edited by Bryan A. Garner defines "oath" as a solemn declaration accompanied by a swearing to God or a revered person or thing, that one's statement is true or that one will be bound to a promise. "Affirmation" is defined, op. cit., as a solemn pledge equivalent to an oath but without reference to a supreme being or to swearing.

${ }^{20}$ The exceptions to this general rule are the provisions of sections 208 and 209 of the said Act. In effect, persons with religious objections to oath taking can be exempted from taking oath as well as anyone who is less than the age of 14 years of age at the time of the oath taking or affirmation. 
perjury even if the person has not been sworn or affirmed as a witness before an appropriate official [21]. An example is the US Income Tax Return, which, by law, must be signed as true and correct under penalty of perjury [22].

In the Nigerian Penal Code, under the Section 156, however, such evidence must have been given under oath [23] or under the express provision of law which expressly compels a person to assert what is true of the facts and warns him of the implications of willfully misleading the court vide his testimony. Such express provision is found in section 206 of the Nigerian Evidence Act [24]. The provision of section 156 of the Nigerian Penal Code as it relates to taking of oath is akin to both sections 1 (1) of the English Perjury Act 1911 and 1621 of the United States Code. Therefore, to amount to false evidence or perjury under these tripartite immediately preceding legislation, the statement must equally have been made under oath, with the oath haven been administered by the person legally recognized to do so and without withdrawal from him whatsoever. [25] Lending credence to this, Turner [26] noted that in the case of perjury in an affidavit or the like, the offence is committed when the deponent takes oath to the truth of the affidavit, and it is unnecessary to aver or prove that the affidavit was filed or in any way used.

${ }^{21}$ Perjury. (2020). In Wikipedia. Retrieved 18 February, 2020, from https://.en.m.wikipedia.org

${ }^{22}$ See Section 6065 of title 26, United States Code

${ }^{23}$ Such could be inferred from the definition of 'judicial proceeding' in section 9 of the Act. Laying bare the provision, "judicial proceeding" include any proceeding in the course of which it is lawful to take evidence on oath.

${ }^{24}$ The section provides that any witness who is summoned to give oral evidence shall be cautioned before doing so in the following words: "you are hereby cautioned that if you tell a lie in your testimony in this proceeding or willfully mislead this court, you are liable to be prosecuted and if found guilty, you will be seriously dealt with according to law".

${ }^{25}$ In the English case of $R$ v. Shaw, 6 Cr. App. R. 1023 where licensing justices who held a special preliminary meeting for which there was no statutory authority and had no power to administer an oath, the perjury proceeding was held not to be judicial one. Also, where an oath is administered on a witness by a person authorized by law to do so, there can be no perjury if that person subsequently withdraws. Thus, in $R v$. Lloyd, 19 Q.B.D. 212 (1887), no perjury was held to have been committed in the absence of the registrar who had the competence to receive evidence on oath.

${ }^{26}$ Turner J. W. C. (1964). Kenny Outlines on Criminal Law (18 ${ }^{\text {th }}$ ed., p. 422). London: Cambridge at University Press.
Untrue statements or lack of believe in its truth. Under the various statutes under consideration, it is irrelevant that the statement or testimony of the witness is facially and totally false. The witness renders himself liable to perjury and the allied offence by simply making false statements, or by simply making true assertions which he does not reasonably believe to be true. The ratio has been summarized in these words, 'a man who tells the truth quite unintentionally is morally a liar' [27].

Parol or written testimony. It is without a doubt that neither perjury nor false evidence is limited to either of oral evidence or documented testimony. It encompasses both realms concurrently. It is, therefore, immaterial, for a charge of perjury, that the false testimony or declaration is orally given or merely deduced in writing [28].

Competence of the court or tribunal. The liability under perjury or false evidence has no positive correlation with the competence of the court or tribunal before whom the said offence is believed or claimed to have been committed in some jurisdictions. This competence extends to the composition of the court or tribunal and the venue of the proceeding, whether it is held in a public or an inaccessible place. What is necessary is that the matter where the perjury is alleged, if the suit or matter went into trial, was properly conducted; and to properly conduct a matter entails judicious adherence to the rules of evidence of the jurisdiction in the proceeding. To this end, the jurisdiction of the court and right to fair hearing are not in contemplation. The Queensland Criminal Code Act and the Nigerian Criminal Code Act summarised it with these words:

It is immaterial whether the false testimony is given orally or in writing. It is immaterial whether the court or tribunal is properly constituted, or is held in the proper place, or not, if it actually acts as a court or tribunal in the proceeding in which the testimony is given [29].

With regard to the competence of the court before which the oath or affirmation is taken, the proceeding will amount to coram non judice [30] under

${ }^{27}$ Op. cit, at p. 433

${ }^{28}$ See the fourth paragraph of section 123 of the Queensland Criminal Code Act, and the corresponding section in the Nigerian Criminal Code Act.

29 See the fifth paragraph to section 123 of the Queensland Criminal Code Act and section 117 of the Nigerian Criminal Code Act.

30 Coram non judice is latin for a legal proceeding without a judge, or with a judge who does not have 
the Indian Penal Code 1860 and United States Code if the Court lacks the jurisdiction to entertain the matter in the first place. Section 156 of the Nigerian Penal Code is, however, silent on this. It must be pointed[' out that under the Nigerian Penal Code, even if the oath is improperly administered by an incompetent person, the offence is still committed, if the person who made the false statement was bound by an express provision of the law to state the truth [31].

\section{Punitive Measures and the Requirement of Additional Evidence}

It will not be our intention to dwell on this subheading, given that it does not form part of the main frameworks of this work. We will say a little, nevertheless. First, it is apt to state that various jurisdictions proffer assorted punishments for perjury or false evidence. These differences in punishment range from the years of imprisonments to additional punishment of fine and punishment where the convicted innocent victim of the perjury or false evidence has been executed.

\section{On punishment for perjury, section 124 of the Queensland Criminal Code Act reads:}

Any person who commits perjury is liable to imprisonment for 14 years. If the offender commits the offence in order to procure the conviction of another person for an offence punishable with death or with imprisonment for life, he is liable to imprisonment for life. [32]

In the United States Code, under section 1621 of title 18 , the convict of perjury is entitled to a maximum penalty of five years or an unspecified amount as fine or a concurrence of both the imprisonment and the fine. The Code is silent on the sanction for an offender who commits the offence in order to procure, or actually procures, the conviction of another person charged for a capital offence or an offence punishable with life imprisonment. Conversely, this is what the Nigerian Penal Code has to say about the penalty for false evidence:

Whoever intentionally gives false evidence in any stage of a judicial proceeding or fabricates false evidence for the purpose of its being used in any stage of a judicial proceeding shall be punished with

proper jurisdiction. Such legal proceeding is often rendered null and void on appeal or judicial review.

31 See Perjury in Nigeria. (2020). In Wikipedia. Retrieved 19 February, 2020, from https://en.m.wikipedia.org

32 This provision was reproduced in the Nigerian Criminal Code Act under section 118. imprisonment for a term which may extend to fourteen years and shall also be liable to a fine. Whoever intentionally gives or fabricates false evidence in any other case of a judicial proceeding shall be punished with imprisonment for a term which may extend to seven years and shall also be liable to a fine[33].

Whoever intentionally gives or fabricates false evidence intending thereby to cause or knowing it to be likely that he will thereby cause any person with death shall be punished with imprisonment for a term which may extend to imprisonment for life and shall also be liable to a fine. If an innocent person is convicted and executed in consequence of such false evidence, the person who gave or fabricated such false evidence shall be punishable with death [34].

As crystal clear as these provisions are, it still will not be out of place to throw in the reminder that the imprisonment terms under the various laws are only a maximum penalty, and not in any way mandatory, and lie within the overriding jurisdiction of the court to mete whatever it deems fit in the circumstance. This takes an exception, however, to the capital punishment provided under section 159 of the Nigerian Penal Code captured above.

It should, secondly, be known that no conviction or sentencing would lie where the evidence of the charge for perjury or false evidence proceeds from the uncorroborated or unsubstantiated testimony of one person or witness and nothing more. [35] Although the Nigerian Penal Code is silent on this issue of additional evidence, the position of corroboration still holds sway in the Northern part of the country, thanks to the extant regulatory framework on evidence in the country [36].

This two-witness rule is a necessity in a perjury prosecution under section 1621 of title 18 , United States Code also. Here, the falsity of a statement

\footnotetext{
${ }^{33}$ See section 158 of the Nigerian Penal Code and section 193 of the Indian Penal Code. The Indian Penal Code only makes reference to seven years imprisonment to the exclusion of the fourteen years also provided under the Nigerian Penal Code.

${ }^{34}$ See section 159 op. cit.

${ }^{35}$ See section 125 of the Queensland Criminal Code Act and section 119 of the Nigerian Criminal Code Act. ${ }^{36}$ See section 202 of the Nigerian Evidence Act 2011 
alleged to be perjurious must be established by either the testimony of two independent witnesses or by one witness and independent corroborating evidence which convincingly contradicts the testimony of the accused and is inconsistent with his innocence [37]. This takes from the judge the discretion of solely committing a witness to prison through contempt proceedings even though the veracity of the witness is in doubt [38].

\section{The Basis for Perjury}

The law of perjury or false evidence is founded on the need for litigants to experience and achieve justice when their conflicts come before the court. Consequently, the rationale for criminalizing legal lies cannot be far-fetched; to prevent litigants from usurping of the powers of the court, to instill on litigants and witnesses the credibility and politeness of coming clean before the court and stating the true facts surrounding the subject or object of the dispute, and to prevent the occasion of injustice. If legal falsehood is not penalized, a leeway for false claims, statements and assertions in the justice system will be established, making certain a death of trust in the judiciary.

With that having been said, quite easy one may say, it is apt that certain thoughts follow suit. The thought of what happens to certain categories of litigants like the accused. Should the accused or defendant in a criminal proceeding confess and plead guilty to the crime without more or should he lean on the presumption of innocence and the proof-beyondreasonable-doubt requirements of the law and plead not guilty? And if he does the second, would he or should he not be charged with perjury if the matter becomes res judicata? If that is the state of things, should every accused person who pleaded not guilty during arraignment and plea but is later found guilty and convicted and knows the evidence against him is so overwhelming not be charged with perjury? If that is also on the affirmative, does it then connote that every accused who is convicted actually committed the crime for which he was charged? Again, should an accused who falsely raises and relies on a defence [39] aimed at misguiding the court or tribunal in his favour not be charged with perjury or false evidence when his defence turns out holding no water and fails?

${ }^{37}$ Department of Justice Manual, 1997 Supplement, at 9-69.265. See also United States v. Forrest, 639 F.2d 1224, 1226 (5th Cir. 1981).

${ }^{38}$ It was held in Maduabum v. Nwosu (2009) LPELR4455 (CA) that where the veracity of a witness is in doubt as in this case, the law is that his evidence should carry no weight at all. The demeanor of the witness is therefore unnecessary in a charge for perjury.

39 Take several defences into consideration, like the defence of alibi, the defence of insanity, the defence of intoxication, the defence of self defence, defence of immature age, and the whole gamut of defences permitted by law.
Should the rationale for making a false statement, testimony or declaration be considered immaterial? What if making such false statement is the only means of survival known to the defendant and conceding to the truth would mean letting go of what has the capacity of keeping himself and other dependent indigents? And if, for imagination sake, such false testimony is exempted from being perjurious, would that not be a floodgate for more exceptions, given that everyone would have justifiable reasons for doing what they do? Or should an objective criteria and test be the sole tool under consideration here? On another thought, should a witness whose evidence is fundamentally contradictory not be declared perjured and what should the court do in conflicting evidences? [40].

Should plaintiffs and claimants who wrongfully and without reasonable believe in their claim and falsely testify in their own cases not be charged with perjury or false evidence, or is the offence only a gift to the parties at the shielding end of suits? If the purpose of perjury or false evidence is to, among others, prevent the obstruction of justice and instill in litigants and witnesses the caution of coming clean and telling the truth before the court, should plaintiffs and their witnesses be open to be liable to perjury? And would not doing so not amount to raising an irrebuttable presumption in favour of the plaintiff to the effect that the case of the plaintiff is always true? The comment on perjury by the United States judiciary in the case of United States v. Dunnigan [41] is axiomatic on the current position of the law of perjury or false evidence toward this direction. In that case it was stated that perjury requires proof that a defendant, while under oath, knowingly made a false statement as to material facts. Note should be taken of the word "defendant".

With these thoughts posed, we hope to make clearer the basis for the law of perjury, any loophole in the law sealed and our examination of judicial attitude on the subject matter will loose any vagueness that may be built around it.

\section{Judicial Attitude toward Falsehood}

We have, without a shadow of doubt, stated the oblivious in the obvious through the thoughts posed in the immediately preceding heading. It is now our goal to take a profound look at the attitude of our courts toward perjury vide the reasoning, obiters and pronouncements of the judiciary. We are taking this

\footnotetext{
${ }^{40}$ An evidence is contradictory where a particular witness avers two different facts in the same matter, and an evidence is conflicting where the testimony of different witnesses are in disagreement and not consistent with the material facts of the claim or defence. Such was the holding of the Nigerian Court of Appeal in Alibco Nigeria Limited \& Anor v. Captain Nwanyanwu (2015) LPELR-26731(CA) ${ }^{41} 507$ U.S. 87, 94 (1993)
} 
route chiefly for the fact that the law is what the judges say it is and an action for perjury is only successfully upon the affirmative pronouncement of the court and nothing more. The attitude of the court in matters of perjury is mobile, evolving and imprecise due to the peculiarity of facts surrounding cases and uniqueness of the interrogations therein.

In the foremost, a dichotomy is often made between willful perjury and memory-related perjury. While willful perjury will satisfy the "knowingly" element of the offence, the latter is a false statement provided as a result of confusion, mistake, faulty memory, carelessness and misunderstanding, and the court will not convict a witness or deponent on the basis of a perjury which is memory related [42]. This position can raise doubt in the minds of federal, public and private prosecutors on the distinguishing line between both kinds of perjury and what the court will hold as perjurious. A principle culled from this is that where the evidence of a witness in a judicial proceeding contradicts his earlier documented statement made or given, such contradiction cannot furnish a ground for his perjury conviction as an accused where the contradicting statements are not established before the Court. Such was the holding of the apex Court of Nigeria in Joshua v. The Queen [43] where, although, the testimony of a witness at the trial substantially differed from his original written statement made to the police, he was not convicted of perjury [44]. It follows to say that where the contradicting statements are evidenced before the court, such a witness may be convicted for perjury as long as a corresponding witness whose testimony materially substantiates the falsity is made available. But where the conflict is between the witnesses of the litigant, it is unlikely that perjury will be brought whether or not the conflict is pleaded before the court. This is due to the dilemma of the prosecuting attorney on who to charge for perjury; the witness, the

${ }^{42}$ See United States v. Dean 55 F.3d 640, 659 (D.C. Cir. 1995) and United States v. Dunnigan, 507 U.S. 87, 94 (1993)

${ }^{43}$ Supra

44 In that case, the accused, a Customary Court President, was charged with demanding and with receiving, money to favour a litigant. A witness, who is said to be the conduit of the charge, denied the corruption when first testifying before a magistrate. He later testified against the accused after a prosecution was begun against him for making a false statement at the police. When the witness was re-examined by the trial judge, he said there was no difference between his original written statement to the police and his evidence at the trial. He was convicted, but later had the conviction upturned when it was established that the written statement made to the police was not produced in trial. litigant the witness is testifying for or both. This dilemma is made manifest by the dearth of statutory and judicial stand on this.

As the law has come to be known, willfully providing false answers to questions asked which bothers on facts relevant to the fact in issue is perjurious. This is common where the examiner puts linking questions to the witness and the witness, in an attempt to avoid the next foreseeable indictable question, provides a false answer to the very question asked. Such was the occurrence in $R$. v. Onward [45] where the accused, who was a poorly paid clerk, was charged with stealing some petrol drums of reasonable value. In the course of the trial, he was asked if he was the owner of a particular car, which he vehemently denied. On discovery of his ownership of the car, he was charged with perjury and convicted therein. His conviction stood despite his argument that the false statement was immaterial in the proceeding because the direction of the question was not a fact in issue. In rejecting his argument, the court logically thought that since the prosecution suspected that he bought the car in question from the proceeds of the theft, the ownership of the car was material to the proceeding [46]. It has recently been held that a charge for perjury is not trammeled by statute of limitation and can be brought at any time within which the said false statement is discovered to have been made [47].

However, it also appears genuine that a literally truthful answer given by a witness under oath in a judicial proceeding cannot constitute perjury, no matter how much the witness intended to mislead the court by his answer. Indeed, it is irrelevant whether the witness intends his answer to mislead or intends a pattern of answers to mislead, as long as the answers are truthful or literally truthful [48]. On this, Chief Justice Warren Burger of the United States Supreme Court, sitting on an appeal, wrote for a unanimous Court that responses to questions made under oath that relayed truthful information in and of themselves but were intended to arguably mislead or evade the

\footnotetext{
45 (1955) WNLR. 28

46 See also the nineteenth century case $R$. v. Baker (1895) 1 Q.B. 797. In this case, the accused was charged with the offence of selling beer without a licence and had falsely and had previously testified on oath that on a previous occasion when he was charged with a similar offence, the plea of guilty put in on his behalf was without his knowledge, authorisation and will. The Court convicted him on perjury since the statement affected his credit as a witness.

47 The Attorney General of Ekiti State v. The Commissioner of Police of Ekiti State (2018) LPELR44421(CA)

${ }^{48}$ See The Rebuttal: Allegations of Perjury. (2020).

Retrieved 19 February, 2020, from https://.nytimes.com/specials/starr/clinton/response.
} 
examiner could not be prosecuted as perjury. [49] This was the position in the leading case on the law of perjury in the United States, United States v. Bronston. [50] We will briefly reproduce the facts of the case, the event in Court as well as the holding of the United States judiciary.

Samuel Bronston was a New York-based movie producer who, between 1959 and 1964, made films in various European countries as Samuel Bronston Productions Incorporated, a company he wholly owned. As part of its business operations, the company maintained thirty seven separate accounts in five different countries in which it did business where it took advantage of lower production costs. The company filed for federal bankruptcy protection in 1964 after the epic, The Fall of the Roman Empire, failed. Two years later, its owner, Samuel Bronston, was being questioned under oath at a creditors' committee meeting about the company's overseas assets. During the questioning, one of the questions put to him was if he had ever had any bank accounts in Swiss banks. He answered this by stating that the company had an account in Zurich for about six months. The matter was referred to federal prosecutors who secured a perjury indictment against Bronston upon the discovery that Bronston had, personally, had an account with the International Credit Bank in Geneva on which he made deposits and drew checks which summed up to $\$ 180,000$ (one hundred and eighty thousand dollars) during the five years in which the company was active and closed just before the bankruptcy filing. The United States District Court for the Southern District of New York, in 1971, held the accused guilty and convicted him [51] on the contention that he intentionally answered the questions by referring to the company's account in Zurich instead of his own personal account leaving the impression that he did not and never had an account in Switzerland [52]. On appeal, the Supreme Court, in unanimously rejecting this theory of perjury, emphatically held that implications and impressions alone do not rise to the

49

https://en.m.wikipedia.org/wiki/Bronston_v._United_St ates. This principle appears to carve out the mens rea in the crime and make it unaccountable. Saying that it is immaterial the misleading intention of the examiner could be saying that mens rea is not only immaterial but also unimportant, and the unimportance here is not to the extent of putting the crime into strict liability genre but making it simply unenforceable. This is, however, not the intention of the principle.

50409 U.S. 352 (1973).

${ }^{51}$ The conviction was after seven hours of deliberations by the Jury, during which they requested not only additional instructions but that the original instructions be read back to them, as well as reviewing several exhibits in the case.

52453 F.2d 555 (2d Cir. 1971) level of perjury, and that Bronston therefore could not have committed perjury [53].

The United States Supreme Court provided several rationales for holding that literally true, nonresponsive answers are by definition non-perjurious, mindless of their implications. One of such rationales was that a witness is not obligated to assist the interrogator in the task of asking specific questions since the onus ever rests on the interrogator to ask precise questions. [54]. It further stated that there is no reason why legislature would intend the drastic sanction of a perjury prosecution to cure a testimonial hitches that could readily have been reached with a single additional question by counsel. And the question that may come to mind is whether the question "have you ever had any bank accounts in Swiss banks, Mr. Bronston?" is not precise enough. That we will answer in the affirmative due to the technicality of the examination. Even though, and rightly so, the decision in Broston creates loopholes in perjury legislation, it has not been overruled amidst the queue of criticisms showered on it and we totally align with it.

The circumstances surrounding the Samuel Bronston's case have been distinguished from subsequent circumstances. It can be inferred from the decision in Bronston that where the question asked the witness is devoid of fundamental ambiguity and is clothed with preciseness, it is nearly impossible for conviction for perjury not to lie. Such was the situation in United States v. Robbins [55]. In that case, Robbins was testifying about a company he had formed called MacArthur and 11th Properties. His examiner mistakenly asked about "11th and Meridian" and Robbins answered that that name "11th and Meridian" was unfamiliar to him but he knew of an "11th and MacArthur". As true as those answers were, they led to a drop in the line of questioning about the real company. Consequently, Robbins was convicted and the conviction was upheld by the Eighth Circuit Court.

\footnotetext{
${ }^{53}$ The Court went further to state the following; "We are not dealing with casual conversation and the Statute does not make it a criminal act for a witness to willfully state any material matter that implies any material matter that he does not believe to be true. The Court took pains to point out the irrelevance of the witness's intent: "A jury should not be permitted to engage in conjecture whether an unresponsive answer, true and complete on its face, was intended to mislead or divert the examiner." 54

https://en.m.wikipedia.org/wiki/Bronston_v._United_St ates

55997 F.2d $390\left(8^{\text {th }}\right.$ Cir. 1993)
} 
In contrast, when a question, or a set of it, is fundamentally ambiguous and therefore capable of being understood and answered in many ways, the answers to the questions posed would lack the sufficiency to support a perjury conviction, as long as the witness truthfully answered the question or set of questions posed based on his understanding of the question [56]. A subjective test of understanding is what this rule relies on and not the subjective test of a reasonable man in society. In United States $v$. Lattimore [57], Lattimore, standing before the Senate Internal Security Subcommittee, was interrogated about his ties with the Communist party. He was asked whether he was a follower of the Communist line and whether he had been a promoter of Communist interests. His answers to both questions were an outright denial. When he was indicted for committing perjury, it was found that the charges were so inconspicuous that he could not be indicted on such. The Court reasoned that, although the government of the day had defined it in one way, the phrase 'a follower of the Communist line' had no generally accepted definition and consequently, the interrogator needed to define and limit the scope of the question before it can be determined whether the witness was perjured. In the similar case of United States v. Bell [58], the witness was asked if he had records that were asked for in the subpoena, be it personal or business records. His answer on the negative, "no, sir, I do not", was the basis for a charge of perjury after it was later proved that his files undoubtedly contained relevant records. The Court, nevertheless, held that the question was ambiguous, and therefore incapable of yielding a perjurious answer. It was the ratio of the Court that the witness interpreted the question to mean whether he had brought the records with him that day, and not whether he had any records anywhere else in the world. This ambiguity doctrine awakens the implication that the burden of asking well defined questions is on the lips of the interrogator or examiner and when he fails to do so, he, or anyone else, cannot successfully urge the court to convict the accused on a count of false evidence.

In distinguishing material facts from Bronston's in order to hold a conviction, it has also been held [59] that where an unequivocal, direct and fully responsive answer is given to a question mistakenly asked and the witness or testifier knows the

\footnotetext{
${ }^{56}$ See the cases of United States v. Lattimore, $127 \mathrm{~F}$. Supp. 405 (D.D.C. 1955); United States v. Bell, 623 F.2d 1132, 1337 (5th Cir. 1980); United States $v$. Finucan, 708 F.2d 838, 848 (1st Cir. 1983); United States v. Lighte, 782 F.2d 367, 375 (2d Cir. 1986); and United States v. Tonelli, 577 F.2d 194, 199 (3d Cir. 1978).

${ }^{57}$ Supra

58470 F.2d 178 (5 $5^{\text {th }}$ Cir. 1973)

${ }^{59}$ United States v. DeZarn, 157 F.3d 1042, 1051 (6 $^{\text {th }}$ Cir. 1998)
}

correct and supposed question which ought to be asked but intentionally answers the one mistakenly asked, such false answer amounts to perjury or giving false evidence however true the unequivocal answer may be. In the 1990 case of United States v. DeZarn, [60] for example, the accused, a Kentucky adjutant general, was being questioned under oath by one Colonel Robert Tripp of the Army Inspector General's office about a 1990 Preakness Day party, which he attended. There he was mistakenly asked about a 1991 party, which was far from being the subject matter of the inquiry. He testified truthfully about it. (The inquiry was related with an investigation into certain Hatch Act violations in 1990 by officers of the Kentucky National Guard). Another Guard officer later came to Col. Tripp and his colleagues with new information which did provide evidence for some of the allegations, and revealed the involvement DeZarn in the 1990 party. This substantiated testimony was enough to indict, and was actually what indicted, DeZarn on a perjury charge a few years upwards. The legal rhetorics of his attorneys to dismiss the charge on the ground that DeZarn's answers were literally true were anything but successful because other witnesses had answered questions about the 1991 party with reference to that of 1990 . In 1998, his conviction was upheld by a Sixth Circuit panel sitting on appeal at the Eastern District of Michigan in the United States. It has been observed [61] that this decision appears to place the witness at risk if he or she subjectively misinterprets the state of mind of the interrogator and gives a literally true answer. This decision seems to be in direct conflict with the rationale adduced in Bronston's case, thereby inferring that a witness is obligated to assist the interrogator in the task of clarifying the questions he asks. The onus will invariably rest on the witness to repair the mistake of the interrogator.

Despite the fore-goings, the position of the law is still unknown where the witness makes the court, tribunal or enquiry presume he is oblivious of the question asked and cannot, therefore, proffer an answer devoid of falsehood, even where the presumption he caused the tribunal or court to hold is false in itself. In other words, it is in doubt whether a witness can be committed for perjury where he answers 'I don't know', or employs a phrase so synonymous with that, to a question asked in a bid to evade contradicting his evidence via the proceeding questions which is likely to naturally flow. What is certain is that the witness cannot be coerced to answer what he avers not to know but what is uncertain is the perjurious tendency of the answers. Answers such as this are unlikely to be perjurious, however, because it is not a direct unequivocal answer to the question asked and is

\footnotetext{
${ }^{60}$ Supra

${ }^{61}$ Barry Tarlow, May 1999; RICO Report Champion; retrieved from <www.nacdl.org> accessed 25 February
} 2020. 
unlikely to have any effect on the outcome of the proceeding. An 'I don't know' answer will not be judged in the same light with an 'I was not at home' or 'I was at school' false responses to the question of 'where were you when Peter was robbed'. The reason is simple; the last two are direct and unequivocal answers to the question and are highly misleading but same cannot be said of the first. Since this can be a deflated alibi, it connotes that alibi, where not established and is rejected, can be perjurious.

\section{CONCLUSION}

Notwithstanding the slight variances in the various statutes on perjury considered, it is unambiguous what actually constitutes perjury. Whether on oath or out of it, in a competent tribunal or one without jurisdiction, perjury is a daily occurrence within juridical and legal confines and can be used to both usurp the power of the courts and occasion substantial injustice, resulting in miscarriages of justice. Given that our courts are courts of facts and not of truth, and one, more often, cannot discern what the truth really is by merely putting his ears or eyes to use in court, it makes for a pathetic realisation that most judicial pronouncements and decisions are often wrongly arrived at, thanks to perjury taking the guise of false testimonies, declarations and evidences which conventionally parade our court rooms and judicial proceedings.

With the wide scope of the elements and constituents of the offence, the basis for the law, what actually is perjurious, the requirements for conviction and immunity of perjury to limitation of time, it is somewhat surprising that difficulty still arises in ascertaining the relevance of this aspect of the law in our contemporary day as could be gleaned in its unenforceability. Indeed, it is difficult pinning a witness to the bars of perjury, and these bugbear are myriads in structure. One of such challenges faced is that the judge cannot, suo motu, infer incredibility and untruthfulness on a witness by merely hearing him testify or make declarations in a judicial proceeding [62]. This position is unfettered by the body language of the witness. No matter how false a statement is or how untrue a deposition is discovered to be, such perjury is only successfully enforceable in the face of the corroborative testimony of two witnesses or one other witness substantiating a material evidence already in existence. Even where a judge, who is presiding on a matter, reasonably believes the witness is outrageously giving false statement, such judge cannot convict the witness

${ }^{62}$ It is true that approving such would allow for disclosure of certain falsehood. But it also is true that allowing such would mean calling on sentiments to take the place of rational reasoning in decision making, and the negative consequences of this is better imagined than experienced. without corroborating testimonies or evidence accompanying a formal charge being proffered against the contemnor in the proper manner. At best, what the judge can do, as revealed in the above-mentioned Nigerian case of Maduabum, is attach no weight to the evidence adduced by the witness.

These challenges are merely a shadow of the real thing. The real thing breathes around the fact that oral answers in a proceeding that can be stamped perjurious are uncertain and may continue to be so with evolution of peculiar circumstances, making the telling of lies easily justifiable. Also, while on the one side a witness is not to be burdened with ensuring that the interrogator asks his questions rightly with sublime explanations as to what really is meant by his questions as held in Bronston, witnesses are, on the second hand, as observed in DeZarn, saddled with the onus of repairing the mistake of the interrogator. The confluence at which these two obligations are not expected to collide is almost impossible. Another challenge is found in the rule which does not allow a witness with contradicting statements and testimonies before the court to be successfully charged with perjury, even when such perjury is not memory-related. An added challenge is the imprudence of the law shown in the attitude of public and private attorneys or legal practitioners in almost entirely taking their eyes off perjury or false evidence and placing them on things perceived to be more worthy of the investment of their time, energy and resources. This comes as a pity when it is realized that failed defences to criminal charges ought to fall within the purview of actionable perjury.

Amidst these surmountable challenges is the unavoidable jigsaw which stems from the enforcement of perjury on the one side and on the other hand, the state of the justice system when witnesses stand back from testifying in court or deposing to written evidences for fear of becoming victims of perjury charges. The way out here is certainly not in abandoning the enforcement of the law of perjury but in limiting its definition while ensuring that interrogators, questioners and examiners ask their questions in a way that will leave no room for ambiguity or vagueness. The scope of perjury should, however, extend to plaintiffs and claimants in civil suits, for these category of persons are not always truthful in their claims and averments. The lacuna on conflicting evidence, as well as who is to be charged after it is settled that conflicting evidence should be circumstantially perjurious, should be sealed.

Ultimately, it is also our suggestive submissions that perjury be extended to cover persons who aided or counseled the falsehood. This emanates from the realisation that certain perjured witnesses and deponents are abetted and counseled by the attorneys and lawyers representing them. These attorneys will go thick and thorns to get judgments and rulings in favour of their clients thus ever willing to misguide the court at 
the most minute of opportunities. While doing this, the various penalties stipulated for any and all the shades of perjury should, as adequate and laudable as they are, be strictly followed and meted by our courts after careful examination of the testimony and evidence containing the particulars of the particular perjury. The department and ministries of justice in various countries and their equivalence are further encouraged to convene educative and reminder conferences on the effect of perjury on the justice system and the need to enforce it for lawyers and the general public. This way, the theory of deterrence as a goal of criminal law will be somewhat attained, and justice will begin to gradually revert to our justice system as the confidence lost will be reposed. It will then be history that persons truly entitled to a claim or right are denied those claims and rights and those not entitled go home rejoicing with such declarations with scoffed smiles.

\section{REFERENCES}

1. Farmer, L. (2008). Crime, Definitions of. In Cane and Conoghan (Eds.), The New Oxford Comapanion to Law (p. 263). Oxford University Press.

2. Garner, B. A. (ed). (2012). Black's Law Dictionary (10th ed, p. 451). Thomson Reuters.

3. Ogbah I. (2017). Defence of Alibi (pp. 185-186). Legal Jurisprudence Limited.

4. Turner, J. W. C. (1964). Kenny Outlines on Criminal Law (18th ed., p. 422). London: Cambridge at University Press. 